\title{
Effect of Sprinter Pattern Bridging Exercise using Theraband on Activation of Lower Extremity and Abdominal Muscle
}

\author{
Gwanho Kim ${ }^{a}{ }^{\oplus}$, Donghyun $Y^{\mathrm{b}}{ }^{\oplus}$, Jongeun Yim ${ }^{\mathrm{c}}$

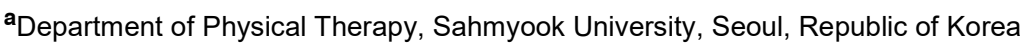 \\ ${ }^{b}$ Department of Physical Therapy, The Graduate School, Sahmyook University, Seoul, Republic of Korea \\ ${ }^{\mathbf{c}}$ Department of Physical Therapy, Sahmyook University, Seoul, Republic of Korea
}

Objective: The purpose of this study was to investigate the effect of sprinter pattern bridging exercise using theraband on activation of lower extremity and abdominal muscle and to find out postures that can effectively improve abdominal and lower extremity muscle strength and increase abdominal stability.

\begin{abstract}
Methods: This study was designed as a cross-sectional study. The following research was done with applicants attending $\mathrm{S}$ university in Seoul to compare the difference in muscle activity between one-leg-Support bridging exercise and sprinter-pattern bridging exercise using theraband. For 48 study participants, we first measured their MVC. Then, we applied one-leg-support bridging exercise and sprinter-pattern bridging exercise at random order. These data were expressed as the percentage of maximal voluntary contraction (\%MVC).Electromyography analysis was performed by measuring the external obliques, internal obliques, biceps femoris, and gluteus maximus.
\end{abstract}

Results: There was a statistically significant increment of muscle activity in external and internal oblique muscle $(\mathrm{p}<0.001)$ by sprinter-pattern bridging exercise using theraband. On the lower body, statistically significant increment of muscle activity in biceps femoris and gluteus maximus was found $(\mathrm{p}<0.05)$. On the other hand, on erector spinae, there was statistically significant decrease in muscle activity $(\mathrm{p}<0.05)$.

Conclusions: Efficient treatment is expected when sprinter-pattern bridging exercise using theraband is applied clinically.For patients with chronic knee and ankle pain who have difficulty bearing weight, including low back pain and internal rotation of the femur, starting with a low weight bearing, we think it will be helpful in planning systematic training aimed at progressively strengthening the lower extremities.

Key Words: Bridging exercise, Gluteus maximus, Elector spinae, Abdominal muscle, Hamstring

서론

닫힌 사슬운동 형태인 교각운동(bridging exercise)은 허리와 체간의 안정화를 위한 근육만이 아니라 엉덩이 와 대퇴의 근력 증진 방법을 위해 사용되고 있다[1]. 인체는 하나의 연결체계이기 때문에 닫힌 사슬운동시 한 부위의 근육만을 사용하는 것이 아니라 닫힌 사슬 안에 있는 모든 근육이 동원된다[2]. 그러므로 교각운 동은 요부의 겉근육(global muscle)과 속근육(local muscle)의 사용으로 요부와 관련된 분절들을 안정화하
며 움직임을 효율적으로 낼 수 있게 만들어주는 운동 이며, 근육 협력 패턴을 재교육하기 위해 사용되는 운 동이기도 하다[3]. 현재 복부의 근력 강화를 위해 윗몸 일으키기(sit-up) 및 컬업(curl-up) 등 여러 방법으로 운 동이 진행되고 있다[4]. 하지만 이 운동방법들이 복부 근 강화에 효과가 있더라도, 이 운동들은 척추에 부담 이 되기 때문에 부상을 입을 수도 있다[5]. 그에 비해 교각운동은 발에 체중 부하와 함께 무릎 서기 자세 (kneeling)를 수행하는 중요한 동작이면서 앉은 자세에 서 서기(sit to stand)동작의 자세 조절 능력을 증진시키

Received: Jun 1, 2021 Revised: Jun 23, 2021 Accepted: Jun 28, 2021

Corresponding author: Jongeun Yim(ORCID https://orcid.org/0000-0001-7510-8233)

Department of Physical Therapy, Sahmyook University

Hwarangro 815, Nowon-gu, Seoul, Republic of Korea [01795]

Tel: + 82-2-3399-1635 Fax: + 82-2-3399-1639 E-mail: jeyim@syu.ac.kr

This is an Open-Access article distributed under the terms of the Creative Commons Attribution Non-Commercial License (http://creativecommons.org/licenses/ by-nc/4.0) which permits unrestricted non-commercial use, distribution, and reproduction in any medium, provided the original work is properly cited.

Copyright @ 2021 Korean Academy of Physical Therapy Rehabilitation Science 
며, 보행에서의 입각기 준비를 위한 하부 척추 근육과 고관절 폄근을 강화하는 운동이다[6].

골반을 고정하여 복부의 안정성을 높이는 근육시스템에는 후방경사슬링, 전방경사슬링, 종적슬링, 외측슬링이 있다[7]. 이러한 인체 슬링을 사용하여 하지뿐만 아니라 상지의 움 직임을 통해 복부의 근활성도를 증진시킬 수 있다. 복부근 육의 근활성도는 신체의 자세와 과제에 따라 다르며[8], 복부의 근활성도와 안정성은 원위부 상지 또는 하지의 움직 임과 결합될 때 더 효과적으로 증가된다고 보고하였다[9]. 위의 연구들을 바탕으로, 하지뿐만 아니라 상지와 하지를 통합적으로 움직이는 스프린터 패턴(sprinter pattern)을 교각운동에 적용하고자 하였다.

스프린터 패턴은 고유수용성신경근촉진법(proprioceptive neuromuscular facilitation; PNF) 개념을 바탕으로 Dietz 가 보행주기 중 일어나는 상지와 하지의 운동 패턴과 동작 을 PNF의 개별 패턴을 통합하여 달리는 사람(sprinter)과 스케이터 타는 사람(skater)의 두 동작으로 구분하여 분석 한 동작이다[10]. 스프린터 패턴에 대한 선행 연구들을 살 펴보면, 일반인에게 선 자세에서 스프린터 패턴을 적용한 실험에서 복직근, 양측의 외복사근, 내복사근에서 근활성 도의 증가를 발견하였으며, 적용한 그룹의 균형능력 또한 증가함을 발견하였다[11]. 또한, 스프린터 패턴을 뇌졸중 환자에게 적용한 연구에서 내측광근과 외측슬괵근에서 근 활성도의 유의미한 증가를 발견하였다. 또한, 정적 및 동 적 균형 능력에 있어서도 유의한 증가를 발견하였다[12]. 위의 연구를 바탕으로, 스프린터 패턴의 복부근, 내측광근, 외측슬괵근의 근활성도의 증가를 확인하였고, 선자세에서 진행된 선행연구에서 적용대상자가 체중부하를 하기 어려 울 경우를 고려하여 앙와위(supine) 자세에서의 교각운동 과의 결합을 적용하고자 하였다.

지금까지 복부 안정화 운동을 바탕으로 다양한 방법들 이 연구되고 있다. 대표적인 방법으로 브레이싱(abdominal bracing maneuver) 방법과 드로우인(abdominal draw-in maneuver) 방법과 윗몸일으키기(sit-up) 및 컬업(curl-up) 방법이 있다. 브레이싱(bracing) 방법과 드로우인(abdominal draw-in maneuver) 단독방법의 경우 하지와 상지가 직접 적으로 개입하지 않고 복부근육만 수축하게 된다. 그렇기 에 대상자에게 하지 근력 강화를 위한 다른 운동 또한 중 재로 사용해야 한다는 점과 운동을 지도함에 있어 스테빌 라이져(Stabilizer)와 같은 장비 없이 복부 근수축을 지도하 는데 어려움이 있다는 점이 있다. 하지만 세라밴드를 이용한 스프린터 패턴 결합 교각운동은 상지의 움직임을 통해 상 하지의 보행패턴(sprinter pattern)을 연습한다는 점[10]과 요추의 하중을 증가시키지 않는다는 이점이 있다. 이에, 본 연구는 한 다리 지지 교각 운동 자세와 한 다리 지지 교각 운동 자세에서 세라밴드를 이용하여 스프린터 패턴을 결합
한 자세의 근활성도를 비교해 보고 효과적으로 복부와 하지 근력을 증진시키고 복부의 안정성을 증가시킬 수 있는 자 세에 대해 알아보고 그 방법에 대해서 제안해 보고자 한다.

\section{연구 방법}

\section{연구대상}

본 연구의 대상자는 $\mathrm{S}$ 대학교에 재학 중인 48 명의 학생 들로 하였다. 또한, 본 연구를 이해하고 적극적으로 연구 에 참여 의사를 밝힌 자로, 모든 연구대상자의 동의를 구 한 후 연구에 자발적으로 참여한 자로 하였다. 연구대상자 의 배제 기준은 최근 6 개월 이내에 허리통증이 있었던 자, 독립적으로 보행을 하지 못하는 자, 체간 및 다리의 근골 격계와 관련된 외과적 병력이나 신경학적 병력이 있는 자, 동작 수행 시에 통증을 호소하거나 동작이 불가능한 자로 하였다. 삼육대학교 연구 윤리위원회의 승인(2-7001793AB-N-012019105HR)을 받은 후 진행하였다.

\section{연구절차 및 방법}

본 연구는 한 다리 지지 교각 운동 자세, 세라밴드를 이용한 스프린터 패턴 교각 운동자세의 하지 및 체간의 근활성도를 측정하였다. 각 자세마다 3회 실시하였고, 1회 당 5초간 실시하였으며, 근피로 예방을 위해 각 교각운동 이 끝날 때 마다 1 분 휴식시간을 갖게 하여 근활성도를 측정하였다. 연구자는 실험 전 연구대상자들에게 실험하 고자 하는 운동에 대하여 충분히 설명하고, 3 회 사전 연 습하였다. 본 실험은 대상자 선정기준에 부합한 48 명의 대상자를 대상으로 실험 전 최대 수의적 수축(MVC)을 위해 2 명의 측정자가 실험에 참여하여 5 초간 외복사근, 내복사근, 대퇴이두근, 대둔근의 근수축 값을 3 회 측정하 여 근전도 분석을 시행하였다.

최대 수의적 수축(MVC)의 검사 방법으로는, 외복사근 과 내복사근은 치료사가 대상자의 하체를 고정하고 대상 자에게 대각선 방향으로 들어 올리도록 하여 검사하였다. 기립근은 엎드려 누운 자세에서 치료사가 다리를 고정하 고 몸통을 들어 올리도록 하여 검사하였다. 대퇴이두근은 엎드려 누운 자세에서 치료사가 골반을 고정하여 무릎을 90도 구부린 상태에서 구부리도록 하여 검사하였다. 대둔 근은 엎드려 누운 자세에서 대상자의 무릎을 90 도 구부리 게 한 후 치료사가 상지를 고정하고 고관절 폄을 하도록 하여 개별적 근육 검사를 시행하였다[13].

각 교각 자세에서 발의 위치를 동일화하기 위해, 실험 전 인체 중심선(mid line)에 서 $2 \mathrm{~cm}$ 떨어진 곳에 지지발 을 두도록 하였으며, 들어올린 발은 고관절의 굴곡이 90 도가 되는 지점에서 세라밴드의 저항을 받도록 하였으며, 


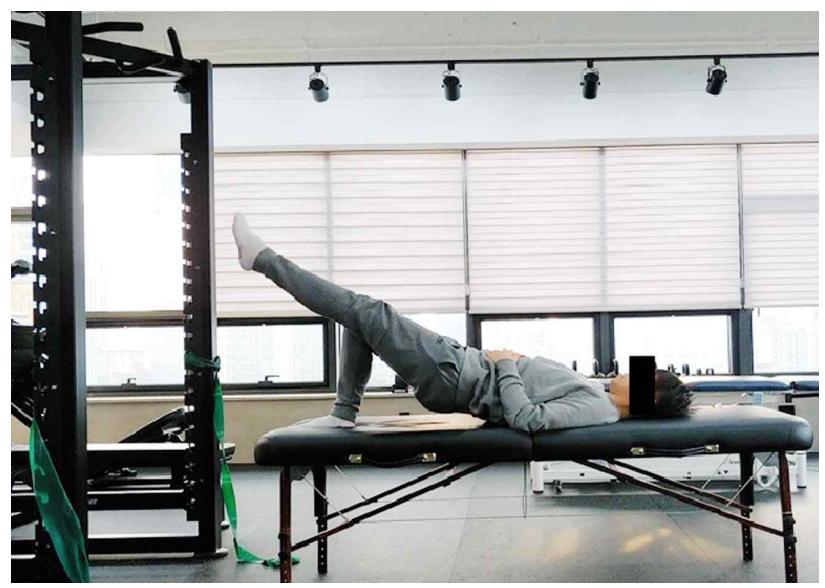

Figure 1. One leg support bridging exercise

교각 운동 자세 끝자세에서 무릎이 90도가 되는 지점에 발을 두도록 하였다. 실험 진행에 있어 시행하는 두 교각 자세에서의 발 위치는 동일하게 하였다. 세라밴드는 고관 절의 굴곡과 견관절의 굴곡에 가장 저항이 많이 갈 수 있 도록 대상자의 아래 방향에 위치하였으며, 굴곡-내전-외회 전에 차례대로 저항이 가도록 저항을 대상자의 아래-바깥 쪽으로 위치하였다. 또한, 지지하는 측 발과 손은 신전-외 전-내회전의 저항을 바닥을 누르면서 실시할 수 있도록 교육하였다.

\section{한다리지지교각 운동 자세}

지지하는 발의 위치는 인체 중심선에서 $2 \mathrm{~cm}$ 떨어진 위치로 하였으며 고관절 0 도 지점에서 무릎의 각도가 90 도를 이루는 곳을 발의 위치로 선택하였다. 양측 상지는 세라밴드를 이용한 스프린터 패턴 교각 운동 자세와 달리 상지의 개입을 없애기 위해 손을 깍지를 낀 후 배위에 올 려두도록 하였다.

\section{세라밴드를 이용한 스프린터 패턴 교각 운동 자세}

지지하는 발은 한 다리 지지 교각 운동 자세와 같게 하 였으며, 상지와 하지에서 스프린터 패턴이 발생 되는 자 세이다. 지지측의 고관절에서는 폄-외전-내회전이 나타나 며, 반대측 고관절에서는 세라밴드의 저항으로 인해 굴곡내전-외회전이 나타나며, 지지측과 동일한 상지에서는 세 라밴드의 저항으로 인해 굴곡-내전-외회전이 나타나며, 반 대측에서는 견관절에서는 신전-외전-내회전이 나타나게 되는 자세이다 $[11,12]$. 세라밴드는 남자는 신장률 $100 \%$ 에서 $2.1 \mathrm{~kg}$ 의 저항이 발생하는 초록밴드를 사용하였으 며, 여자는 신장률 $100 \%$ 에서 $1.7 \mathrm{~kg}$ 의 저항이 발생하는 빨강밴드를 사용하였다.

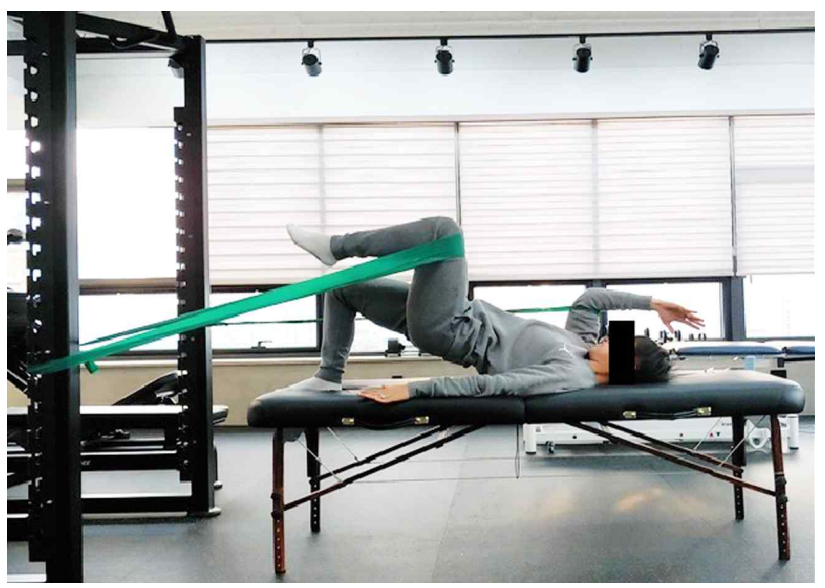

Figure 2. Sprinter pattern bridging exercise using theraband

\section{근전도}

두 교각 운동 자세를 하는 동안 외복사근(external oblique), 내복사근(internal oblique), 기립근(erector spinae), 대퇴 이두근(biceps femoris) 대둔근(gluteus maximus), 근활 성도를 알아보기 위하여 표면근전도(Telemyo $2400 \mathrm{G} 2$ EMG system, Noraxon, USA, 2011)를 사용하였다. 근 전도 신호의 표본 추출률(sampling rate)은 $2000 \mathrm{~Hz}$ 으로 설정하였고, 주파수 대역폭은 30 450 Hz로 하였다.

본 연구에서 측정한 근육의 근전도 신호는 Myoresearch XP Master edition 소프트웨어(2011, Noraxon Inc., USA)를 이용하여 전파정류(full wave rectification)로 처 리 후 RMS(root mean square) $250 \mathrm{~ms}$ 로 설정하여 분석 하였다. 각 조건 마다 엉덩이를 들어 올린 후 엉덩관절과 체간이 0 도인 상태에서 5 초를 측정하였고, 앞 뒤 1 초를 제외한 안정된 3 초를 구간 추출하여 사용하였다. 모든 조 건에서 3회 반복측정 하여 평균값을 구한 후에, $\mathrm{MVC}$ 값 으로 각 근육의 근전도 신호를 표준화하였다.

\section{통계 및 분석방법}

수집된 자료는 윈도우용 통계프로그램 PASW(version 18.0, SPSS Inc., USA)을 사용하였고, 대상자의 일반적 인 특성은 기술통계량(descriptive statistics)으로 분석하 였으며, 교각 운동 자세 조건에 따른 체간 및 하지 근활성 도에 미치는 영향을 알아보기 위해 대응표본 $\mathrm{t}$ 검정 (paired t-test)을 실시하였다. 모든 자료의 통계학적 유의 수준은 $\mathrm{p}<0.05$ 로 하였다. 


\section{결과}

\section{일반적 특성(Table 1)}

본 연구에서의 대상자는 일반인 48 명으로 남자 27 명 여자 21 명이었으며, 평균연령 26.9세 평균 신장 168.58 $\mathrm{cm}$, 평균 체중 $66.06 \mathrm{~kg}$, 평균 체질량지수 $23.11 \mathrm{~kg} / \mathrm{m}^{2}$ 이었다.

\section{교각운동 조건에 따른 복부 및 하지의 근활성도 비교(Table 2)}

외복사근의 근활성도는 세라밴드를 이용한 스프린터 패턴 교각 운동 자세에서 한 다리 지지 교각 운동 자세보 다 유의하게 컸다 $(\mathrm{p}<0.05)$.

내복사근의 근활성도는 세라밴드를 이용한 스프린터 패턴 교각 운동 자세에서 한 다리 지지 교각 운동 자세보 다 유의하게 컸다 $(\mathrm{p}<0.05)$

척추기립근의 근활성도는 세라밴드를 이용한 스프린터 패턴 교각 운동 자세에서 한 다리 지지 교각 운동 자세보 다 유의하게 작았다 $(\mathrm{p}<0.05)$.

대퇴이두근의 근활성도는 세라밴드를 이용한 스프린터 패턴 교각 운동 자세에서 한 다리 지지 교각 운동 자세보 다 유의하게 컸다 $(\mathrm{p}<0.05)$.

대둔근의 근활성도는 세라밴드를 이용한 스프린터 패
턴 교각 운동 자세에서 한 다리 지지 교각 운동 자세보다 유의하게 컸다 $(\mathrm{p}<0.05)$.

\section{고찰}

본 연구는 일반인을 대상으로 선정하여 한 다리 지지 교각 운동과 세라밴드를 이용한 스프린터 패턴 교각 운동 의 복부와 하지의 근활성도의 차이를 비교하여, 효과적인 복부 및 하지의 교각 운동방법을 제안하고자 하였다.

연구결과 외복사근과 내복사근의 $\% \mathrm{MVC}$ 값은 세라밴 드를 이용한 스프린터 패턴 교각 운동은 한 다리지지 교 각 운동보다 유의하게 증가하였다 $(\mathrm{p}<0.05)$.

대퇴이두근과 대둔근의 \%MVC 값은 세라밴드를 이용한 스프린터 패턴 교각 운동이 한 다리지지 교각 운동보다 유의하게 증가하였다 $(\mathrm{p}<0.05)$. 반면, 기립근의 $\% \mathrm{MVC}$ 값은 세라밴드를 이용한 스프린터 패턴 교각 운동이 한 다리 지지 교각 운동 자세보다 유의하게 감소하였다 $(\mathrm{p}$ $<0.05)$.

본 연구에서 검사한 외복사근과 내복사근은 체간의 폄 과 측굴시에 외부의 힘에 대한 체간을 안정화하는 저항력 을 만들고, 골반의 전방경사에 대항하는 힘을 만들어 골 반을 안정화시킨다[1]. 복부근육의 약화는 요추의 전만 (lordosis)과 골반경사의 증가를 만들며 이로 인해 허리통

Table 1. General characteristics of subjects

$(\mathrm{N}=48)$

\begin{tabular}{ll}
\hline & Subject \\
\hline Gender (male/female) & $27 / 21$ \\
Age & $26.93 \pm 6.38$ \\
Height $(\mathrm{cm})$ & $168.58 \pm 7.87$ \\
Weight $(\mathrm{kg})$ & $66.06 \pm 11.90$ \\
BMI $\left(\mathrm{kg} / \mathrm{m}^{2}\right)$ & $23.11 \pm 3.05$ \\
\hline
\end{tabular}

Values are presented as mean \pm standard deviation

Table 2. Comparison of muscle activity between one leg support bridging exercise and sprinter pattern bridging exercise using theraband

$(\mathrm{N}=48)$

\begin{tabular}{lllll}
\hline & & $\begin{array}{l}\text { One leg support } \\
\text { bridging exercise }\end{array}$ & $\begin{array}{l}\text { Sprinter pattern bridging } \\
\text { exercise using theraband }\end{array}$ & \multirow{t}{*}{$\boldsymbol{p})$} \\
\hline \%MVC & External obliques & $10.10 \pm 3.50$ & $16.06 \pm 4.02$ & $-8.98(0.000)$ \\
& Internal obliques & $12.87 \pm 5.13$ & $17.14 \pm 5.76$ & $-7.43(0.000)$ \\
& Hamstring & $38.79 \pm 5.47$ & $40.05 \pm 5.78$ & $-2.65(0.011)$ \\
& Gluteus maximus & $25.46 \pm 5.65$ & $26.68 \pm 5.81$ & $-2.45(0.018)$ \\
& Elector spinae & $28.19 \pm 3.72$ & $26.71 \pm 4.29$ & $2.23(0.030)$ \\
\hline
\end{tabular}

Values are presented as mean \pm standard deviation 


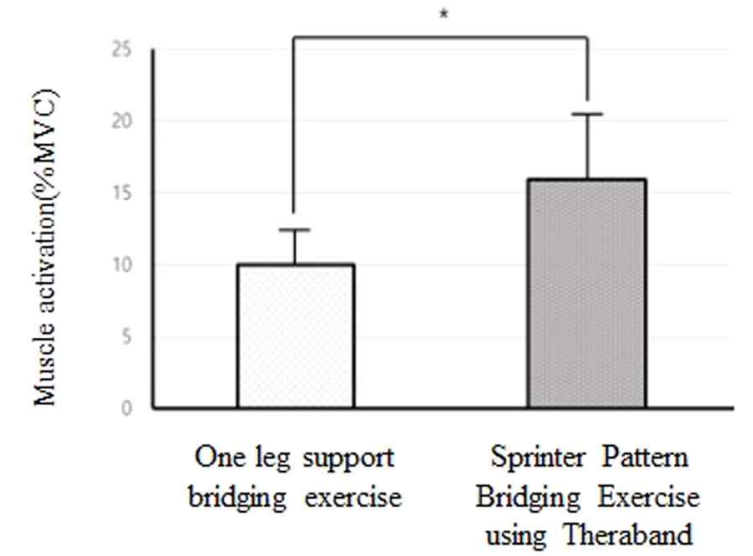

Figure 3. Muscle activation in External obliques

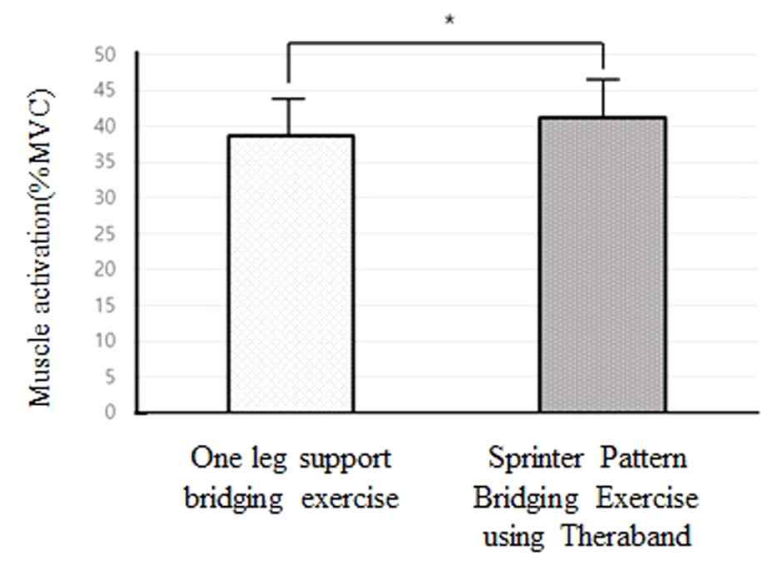

Figure 5. Muscle activation in Hamstring

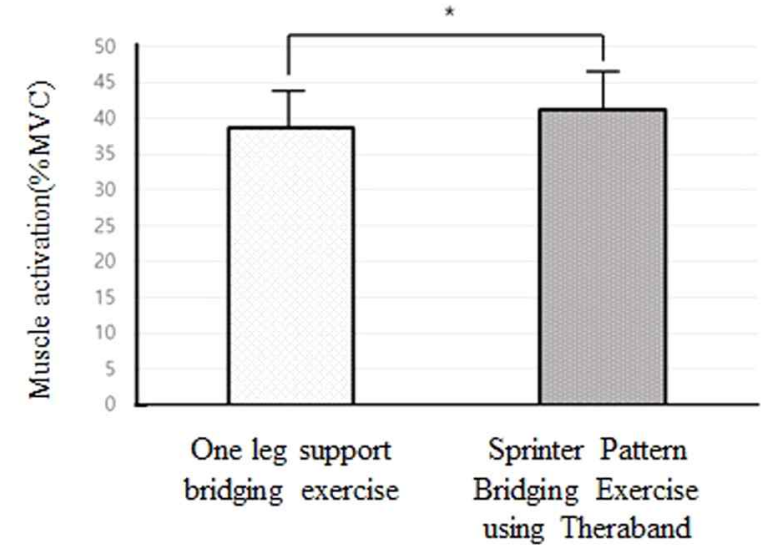

Figure 7. Muscle activation in Elector spinae

증을 유발할 수 있다[14]. 외복사근은 전방경사슬링(anterior oblique sling)의 연결로 인해 반대측 고관절 내전근과 연 결된다[7]. 본 연구에서 세라밴드를 이용한 스프린터 패턴 동작의 거상측 고관절에서 굴곡-내전-외회전이 발생하기 에 고관절 내전근의 활성도의 증가가 전방경사슬링(anterior

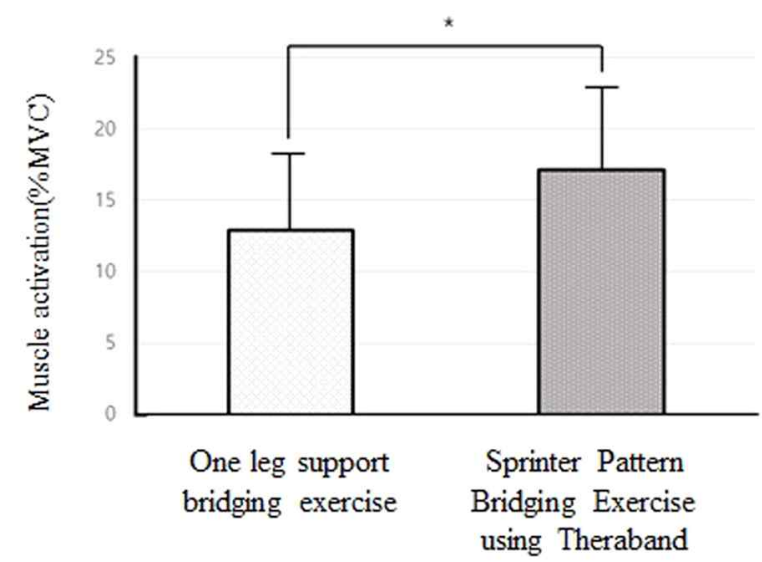

Figure 4. Muscle activation in Internal obliques

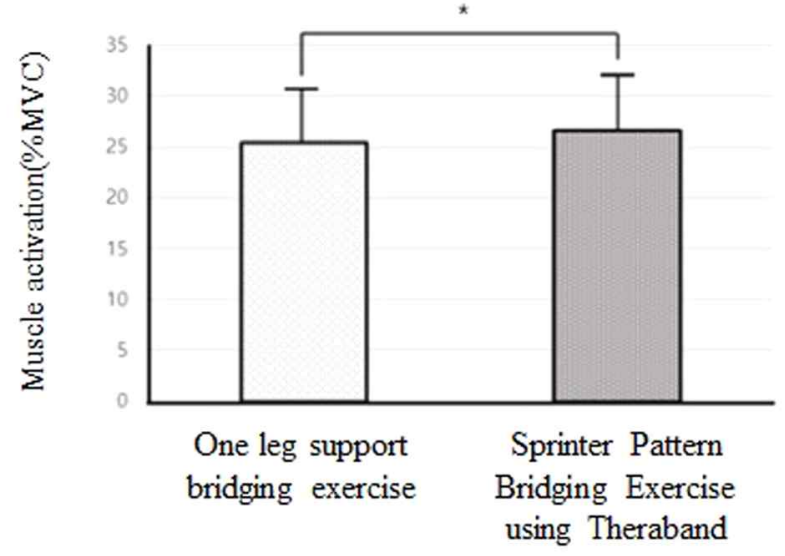

Figure 6. Muscle activation in Gluteus maximus

oblique sling)의 연결을 통해 외복사근의 활성도의 증가 에도 기여했을 것이라 볼 수 있을 것이다.

García-Vaquero 등[15]의 연구에 따르면, 한 다리지 지 교각 운동 자세에서 양다리지지 교각 운동 자세보 다 지지측과 거상측 모두 내복사근의 활성도가 증가한 다고 보고 하였다. Vera-Garcia 등[16]의 연구에 따르 면, 정상 성인의 몸통 안정화 운동에 따른 근활성도 연 구에서 두 다리 지지 교각 자세보다 한 다리만 지지하 는 교각 자세는 다리 거상으로 회전력이 발생되어 기 울어지게 되는데, 이를 방지하기 위해 체중을 지지하는 기립근을 제외하고 거상측 내복사근에서 근활성도가 증가한다고 보고하였다. 위 연구를 바탕으로, 세라밴드 를 이용한 스프린터 패턴 교각 운동 자세는 하체의 회 전력뿐만 아니라, 견관절의 굴곡과 신전 및 내전과 외 전을 통한 회전을 제공하고, 복부가 이에 따라 기울어 지는 것을 막기 위해 한 다리지지 교각 운동보다 근 활 성도가 높았을 것이라 설명할 수 있을 것이다.

복부의 근활성도는 신체자세와 과제에 따라 달라지며 
[8], 인체는 선행적 자세조절을 통해 복부근육을 먼저 수 축시킴으로 복부의 움직임과 반대되는 힘을 생성하여 발 생될 수 있는 자세동요에 대해 척추의 안정성을 확보한다 [17]. 위 연구를 바탕으로, 세라밴드를 이용하여 주어진 움직임 과제에 대해, 선행적 자세조절을 위해 상지와 하 지가 움직이려는 반대 방향에 대해 복부가 자세동요를 저 지하여 반대되는 복부의 힘을 생성한 결과 한 다리지지 교각 운동보다 더 높은 복부근육의 근활성도를 보였을 것 이라 할 수 있을 것이다.

정우식 등[12]은 PNF 스프린터 패턴을 이용하여 뇌졸 중 환자의 하지 근활성도 증가와 보행능력 향상에 관한 연구를 통하여 패턴 결합의 효과를 설명하였고, 일반인에 게 선 자세에서 스프린터 패턴을 적용한 실험에서 지지측 의 외복사근, 내복사근에서 근활성도의 유의한 증가를 발 견하였다. 위 연구와 다르게 본 연구에서는 앙와위 자세 (supine position)에서 교각 운동과 스프린터 패턴을 세라 밴드를 사용하여 결합하여 진행한 결과 지지측의 외복사 근과 내복사근의 활성도의 유의한 증가는 같았다.

본 연구에서 검사한 대둔근과 대퇴이두근은 골반을 후 방경사하는 역할을 하며, 고관절의 신전근으로 작용한다 $[13,18]$. 대둔근의 약화, 복근조절의 결핍, 기립근의 우세 한 근활성도는 고관절의 신전운동 시 요추의 전만 및 골 반의 전방경사에 기여하며 이러한 작용은 만성요통의 원 인이 될 수 있다[19]. 본 연구에서 근활성도가 유의하게 증가한 외복사근과 내복사근의 경우, 골반을 후방경사하 는 역할을 하며, 이를 바탕으로 대둔근과 대퇴이두근과 동시수축하여 골반을 후방경사 하여, 지지측의 기립근의 유의한 근활성도의 저하를 나타냈을 것이라 사료된다. 또 한, 고은경 [20]의 연구를 보면, 교각 운동 시 복부 넣기 시 기립근의 근활성도가 유의하게 감소하였는데, 본 연구 에서도 기립근의 활성도는 유의하게 감소하였다.

대둔근은 후방경사슬링(posterior oblique sling)에 의 해 반대측 광배근과 연결된다[7]. 본 연구에서 지지측 견 관절에서 신전-외전-내회전을 유도했으며, 이는 견관절을 신전-내전-내회전의 역할을 하는 광배근 활성도의 증가를 통해 후방경사슬링(posterior oblique sling)을 통해 연결 되어 있는 대둔근의 활성도 또한 증가시켰을 것이라 볼 수 있을 것이다.

한향완[21]은 닫힌 사슬과 열린 사슬 자세에서 상지에 굴곡, 외전, 외회전 패턴을 사용하여 운동의 끝 범위에서 적용된 저항이 반대편 대퇴이두근의 근활성도의 유의한 증가를 방산(radiation)의 효과로 설명하였다. 본 연구의 경우, 지지측 다리의 반대 견관절에 적용된 패턴이 굴곡, 내전, 외회전이며 사지의 전체적으로 패턴이 적용되었다 는 차이가 있지만, 패턴을 사용한 방산의 효과를 사용한 점과 대퇴이두근에서 유의한 근활성도에 증가를 보였다는
점은 같았다. 위 연구에 따라, 상지의 패턴과 하지의 패턴 과의 결합을 바탕으로 지지하는 다리의 근활성도 간의 연 관성을 세라밴드를 이용한 스프린터 패턴에 의한 방산 (radiation)의 효과 및 후방경사슬링(posterior oblique sling) 연결로 설명할 수 있을 것이다.

본 연구의 제한점은 연구대상자들의 수가 많지 않았고 단면적 연구의 특성상 짧은 연구 기간으로 인해 본 연구 결과를 갖고 장기간의 효과를 판단하기는 어렵다. 또한 일반인을 대상으로 한 연구결과의 특징상 질환을 가지고 있는 대상자에게 일반화되기는 어렵다는 제한점이 있다. 차후 논문에서는 특정 질환자에 대한 대상자에 대해 연구 가 필요하다. 대상자들에게 제공된 세라밴드는 각 개인의 근력을 측정하여 반영하지 못하였음으로, 같은 구성의 성 별에 따라서만 세라밴드의 저항을 구성했다는 제한점이 있다.

\section{결론}

본 연구의 결과를 통하여 세라밴드를 이용한 스프린터 패턴 교각 운동 자세가 한 다리지지 교각 운동 자세보다 외복사근, 내복사근, 대퇴이두근, 대둔근의 근활성도의 증 가가 있음과 기립근에서는 근활성도의 감소가 있음을 입 증하였다. 이로 외복사근, 내복사근, 대퇴이두근, 대둔근의 훈련을 요하는 대상자에게 브레이싱(bracing), 드로우인 (draw-in)방법과 지지면을 바꾸는 방법과 같이 다양한 치 료적 방향으로 사용될 수 있는 자료를 제시할 수 있으며, 추후 임상에서 전방경사로 인한 요통 및 대퇴 내회전을 포함한 체중지지가 어려운 만성 무릎 및 발목 통증 환자 에 대해 적은 체중 부하를 시작으로 점진적인 하지의 근 력강화를 목표로 체계적 훈련을 계획하는데 도움이 될 것 이라 생각한다.

\section{참고문헌}

1. Kisner C, Colby LA, Borstad J, Therapeutic exercise: foundations and techniques: Fa Davis; 2017.

2. Kim EY, Jeong YJ, Song MH, Analysis of the Muscle Activity of the Trunk and the Lower Extremities in Relation to the Initial Bending Angle of the Hip Joint During Bridge Exercise. Journal of Korean academy of orthopaedic manual therapy. 2012. 18(23): 9.

3. Stevens VK, Bouche KG, Mahieu NN, Coorevits PL, Vanderstraeten GG, Danneels LA, Trunk muscle activity in healthy subjects during bridging stabilization exercises. BMC Musculoskelet Disord, 2006. $7(1): 1-8$. 
4. Hildenbrand K, Noble L, Abdominal muscle activity while performing trunk-flexion exercises using the Ab Roller, ABslide, FitBall, and conventionally performed trunk curls. J Athl Train. 2004. 39(1): 37.

5. Richardson C, Jull G, Hides J, Hodges P, Therapeutic exercise for spinal segmental stabilization in low back pain: Churchill Livingstone London; 1999.

6. O'Sullivan SB, Schmitz TJ, Fulk G, Physical rehabilitation: FA Davis; 2019.

7. Vleeming A, A new light on low back pain. The Integrated Function of the Lumbar Spine and Sacroiliac Joints. 1995.

8. Cholewicki J, Vanvliet Iv JJ, Relative contribution of trunk muscles to the stability of the lumbar spine during isometric exertions. Clin Biomech (Bristol, Avon), 2002. 17: 99-105.

9. Hodges PW, Richardson CA, Altered trunk muscle recruitment in people with low back pain with upper limb movement at different speeds. Arch Phys Med Rehabil, 1999. 80(9): 1005-1012.

10. Dietz B, Let's sprint, let's skate: Springer Science \& Business Media; 2009.

11. Seo DY, A Study on the Effects of PNF Sprinter Pattern on Stable and Unstable Surfaces on the Activity and Balance of the Trunk. Gwang ju: Nambu University; 2012.

12. Jeong WS, Jeong JY, Kim CK, Jung DI, Kim KY. Effect of Lower Limb Muscle Activity on Balancing through Sprinter Patterns of PNF. The Korea Contents Society, 2011. 11(3): 281-92.

13. Kendall FP, McCreary EK, Provance P, Rodgers M, Romani W, Muscles: Testing and function, with posture and pain (Kendall, Muscles). LWW. 2005.

14. Rone-Adams SA, Shamus E, Hileman M, Physical Therapists' Evaluation of the Trunk Flexors in Patients With Low Back Pain. J Allied Health, 2004. 2(2): 3.

15. García-Vaquero MP, Moreside JM, Brontons-Gil E, Peco-González N, Vera-Garcia FJ, Trunk muscle activation during stabilization exercises with single and double leg support. J Electromyogr Kinesiol, 2012. 22: 398-406.

16. Vera-Garcia FJ, Moreside JM, McGill SM, MVC techniques to normalize trunk muscle EMG in healthy women. J Electromyogr Kinesiol, 2010. 20(1): 10-16.

17. Aruin AS, Latash ML, Directional specificity of postural muscles in feed-forward postural reactions during fast voluntary arm movements. Exp Brain Res, 1995. 103: 323-332.

18. Levangie PK, Norkin CC, Joint structure and function: a comprehensive analysis. 2011.

19. Sahrmann S, Azevedo DC, Van Dillen L, Diagnosis and treatment of movement system impairment syndromes. Braz J Phys Ther, 2017. 21(6): 391-399.

20. Koh EK, Jang JH, Jung DY. Effect of Abdominal Hollowing on Muscle Activity of Gluteus Maximus and Erector Spinae during Bridging Exercise. The journal of Korean society of physical therap. 2012. 24(5): 319-324.

21. Han HW, Kim SS. Effect of Close kinetic chain and Open kinetic chain Position on Proprioceptive Neuromuscular Facilitation Applied to the Unilateral Upper Extremity on the Muscle Activation of Lower Extremity. PNF and Movement. 2009. 7(3): 17-27. 